\title{
RELATIONSHIP BETWEEN INTERLEUKIN-6 GENE POLYMORPHISM AND HEART FAILURE IN PATIENTS WITH CORONARY ARTERY DISEASE AND OBESITY
}

DOI: 10.36740/WLek202008109

\author{
Pavlo G. Kravchun, Olga I. Kadykova, Natalia G. Ryndina, Svitlana 0. Krapivko, Mykhailo I. Kozhyn, \\ Victoriia I. Zolotaikina \\ KHARKIV NATIONAL MEDICAL UNIVERSITY, KHARKIV, UKRAINE
}

\begin{abstract}
The aim: To examine the association between polymorphisms of the IL-6 gene promoter and HF in patients with CAD and obesity.

Material and methods: 222 patients with coronary artery disease and obesity were identified. Comparison group consisted of 115 patients with coronary artery disease with normal body weight. The groups were comparable in age and sex. The exclusion group consisted of patients with severe concomitant diseases of the respiratory and digestive organs, kidneys and people with cancer. One single nucleotide polymorphisms in the interleukin- 6 promoter region was analyzed. $0 \mathrm{dds}$ ratio (0R) and $95 \%$ confident interval $(95 \% \mathrm{Cl})$ were calculated.

Results: The combined course of coronary artery disease and obesity was characterized by the detection of allele C in 62 patients ( $27.93 \%$ ), allele $\mathrm{G}$ - in 160 patients (72.07 \%), and genotypes CC, CG and GG - at 24 (10.81\%), 67 (30.18\%) and 131 (59.01\%) patients respectively. The results showed that the - $174 \mathrm{G}$ allele and GG genotype in patients with coronary artery disease and obesity were associated with heart failure $\left(0 \mathrm{R}=2.55,95 \% \mathrm{Cl}=[1.72-3.79], \mathrm{X}^{2}=22.8 ; \mathrm{p}<0.05\right)$ and $(0 \mathrm{R}=11.95,95 \% \mathrm{Cl}=[3.41-41.91]$, $\left.X^{2}=22.5 ; p<0.05\right)$, whereas allele $\left(-174\right.$ was associated with a decrease in the risk of heart failure $\left(0 R=0.39,95 \% \mathrm{Cl}=[0.26-0.58], X^{2}=22.75, p<0.05\right)$.

Conclusions: The obtained results testify that the $-174 \mathrm{G}>$ C polymorphism in the interleukin- 6 gene is significantly associated with increased risk of heart failure in patients with coronary artery disease and obesity.
\end{abstract}

KEY WORDS: the polymorphisms of the interleukin- 6 gene, heart failure, coronary artery disease, obesity

Wiad Lek. 2020;73(8):1637-1640

\section{INTRODUCTION}

The incidence and prevalence of heart failure (HF) and its associated mortality is increasing at alarming rates [1]. Despite the progress made in the development of several new therapies in HF management, the overall 5-year mortality rate for HF remains extremely high at nearly $50 \%$ [2]. Recent epidemiologic evidence from the Framingham Heart Study indicates that overweight and obesity are potent indicators and predictors of subsequent clinical HF [1]. Obesity is also an irrespective risk factor for cardiovascular disease, including coronary artery disease (CAD), and HF and is associated with an increased risk of morbidity and mortality $[3,4]$.

CAD represents a health problem worldwide [5]. Though CAD's etiology seems to be multi-factorial and intricate, the most main etiological factor is the atherosclerosis. Atherosclerosis is an inflammatory disease associated with specific pathophysiological reactions in large- and medium-sized arteries [6]. Inflammation plays a central role in the formation of atherosclerosis, and can also be considered a risk factor. In the process of inflammation atherosclerosis involves many humoral factors - interleukins (IL), interferons (IFN), tumor necrosis factors (TNF), colony stimulating factors (CSF). [7]. Furthermore, many modern studies have established links between levels of inflammatory cytokines and atherosclerotic lesions [8]. Interleukin-6 (IL-6) is a glycoprotein that is a multifunctional cytokine that coordinates immune and acute phase inflammatory responses, as well as oncogenesis and hemopoiesis. Produced by cells of the immune system as well as cells that have no direct relationship to the immune system: fibroblasts, keratinocytes, chondrocytes, stromal cells of endometrium, Leydig cells in the testis, vascular smooth muscle cells and endothelial cells and synovial. [9] . Some studies have reported that IL-6 has a wide range of biological activity and acts on different cell types. Moreover, IL-6 is a predictor of endothelial activation and dysfunction. Epidemiological data have demonstrated that IL- 6 is associated with cardiovascular diseases. Last studies have also revealed the association between IL-6 plasma levels and pathology of cardiovascular system [10]. Some scientists have found correlations between concentration of IL-6 and myocardial infarct in apparently healthy patients [11].

However, despite such mechanistic data, the association of raised IL-6 levels with CAD and HF is not a proof of cause. Indeed, coronary lesions may be proinflammatory, causing (rather than being caused by) the elevation of IL-6 levels. One way to clarify the issue of causation is to use a genetic approach. The association of a functional IL-6 
Table 1. Distribution of IL-6 genotypes

\begin{tabular}{|c|c|c|c|c|}
\hline & \multicolumn{3}{|c|}{$n, \%$} & \multirow{2}{*}{ Value } \\
\hline & GG & GC & CC & \\
\hline Case & 131 (59.01 \%) & 67 (30.18\%) & 24 (10.81\%) & \multirow{2}{*}{$p<0.05$} \\
\hline Controls & $7(20 \%)$ & 19 (54.29\%) & 9 (25.71\%) & \\
\hline
\end{tabular}

Table 2. IL-6 genotypes and their association with HF

\begin{tabular}{lc}
\hline & OR $(\mathbf{9 5} \% \mathrm{CI})$ \\
\hline \multirow{2}{*}{ The $-174 G$ allele } & $2.55(1.72-3.79)$ \\
\cline { 2 - 2 } The C-174 allele & $\chi^{2}=22.8 ; \mathrm{p}<0.05$ \\
\hline \multirow{2}{*}{ The GG genotype } & $0.39(0.26-0.58)$ \\
\hline & $\chi^{2}=22.75 ; \mathrm{p}<0.05$ \\
\hline
\end{tabular}

polymorphism with CAD would suggest a causal, rather than passive, association of the cytokine and disease. Thus, it is of some importance to identify polymorphic variants of the IL-6 gene that are functional in vivo in humans and that might thus prove to be useful investigative tools. Recent experimental work has identified the presence of 4 genetic polymorphisms in the IL- 6 gene promoter: $-597 \mathrm{G}>\mathrm{A},-572 \mathrm{G}>\mathrm{C}$, and $-174 \mathrm{G}>\mathrm{C}$, and a fourth locus (position -373), which constitutes a tract of adenine and thymidine residues (the AnTn tract) in varying numbers [12]. IL-6 promoter polymorphisms have been associated with susceptibility to CAD and HF, but with conflicting results in different populations.

\section{THE AIM}

The aim of the present study was to examine the association between polymorphisms of the IL- 6 gene promoter and $\mathrm{HF}$ in patients with CAD and obesity.

\section{MATERIALS AND METHODS}

\section{SUBJECT RECRUITMENT}

Between 2014 and 2016, eligible people were identified and recruited from the electoral roll, and invited to attend a screening clinic close to their home. On arrival at the clinic, the trial was explained to each participant and written consent was obtained. A risk factor questionnaire covering aspects of medical history and lifestyle relevant to CVD was completed. Height, weight, girth at hips and waist, and blood pressure were measured. 222 patients with $\mathrm{CAD}$ and obesity were identified. In the comparison group were included 115 patients with coronary artery disease with normal body weight. The control group consisted of 35 healthy individuals. The groups were comparable in age and sex. The exclusion group consisted of patients with severe concomitant diseases of the respiratory and digestive organs, kidneys and people with cancer.

\section{DNA EXTRACTION AND GENOTYPING}

Genomic DNA was extracted from EDTA anti-coagulated whole blood using a standard Triton X-100 procedure. The DNA was resuspended in TE buffer and quantified using either ultraviolet spectrophotometric methods or NanoDrop ND-1000 (NanoDrop Technologies). One single nucleotide polymoprhisms (SNPs) in the IL-6 promoter region was analysed. IL-6-174G >C (rs1800795) genotypes were determined using fluorescent Polymerase Chain Reaction (PCR) with electrophoretic detection results using reagent kits «SNP-Express” produced by SPC “Liteh” (Russia).

\section{STATISTICAL METHODS}

All loci were tested for deviations from Hardy-Weinberg equilibrium by means of a standard chi-squared test and significant deviations $(\mathrm{p}<0.05)$ were excluded from all subsequent analyses. Odds ratio (OR) and $95 \%$ confident interval (95\% CI) were calculated.

\section{RESULTS AND DISCUSSION}

In the control group allele $\mathrm{C}$ of the polymorphic locus C-174G the IL- 6 gene was found in 47 individuals, which was $67.14 \%$, allele $\mathrm{G}$ was 23 (32.86\%), and genotypes CC, CG and GG were distributed as follows: 9 (25.71\%), $19(54.29 \%)$ and $7(20 \%)$ respectively. The combined course of CAD and obesity was characterized by the detection of allele C in 158 patients (35.59\%), allele $\mathrm{G}$ - in 286 patients (64.41\%), and genotypes CC, CG and GG - at 24 (10.81\%), 67 (30.18 \%) and 131 (59.01\%) patients respectively (Table I).

The frequency of detection of all alleles and genotypes was significantly different from the distribution in the control group in patients with $\mathrm{CAD}$ and obesity $(\mathrm{p}<0.05)$. Thus, allele $\mathrm{C}$ and genotypes CC, CG were less commonly found in patients with a comorbidity of CAD and obesity compared with the control group at $31.55 \%$ and $14.9 \%, 24.11 \%$ respectively, and the allele $\mathrm{G}$ and genotype GG, on the contrary, more often on $31.55 \%$ and $39.01 \%$. Most likely, in patients with CAD and obesity, 
genotype GG and less than $19.01 \%$ genotype CG were found in $19.01 \%$ compared to patients with CAD without obesity $(\mathrm{p}<0.05)$.

The results showed that the $-174 \mathrm{G}$ allele and GG genotype in patients with $\mathrm{CAD}$ and obesity were associated with $\mathrm{HF}$ $\left(\mathrm{OR}=2.55,95 \% \mathrm{CI}=[1.72-3.79], \chi^{2}=22.8 ; \mathrm{p}<0.05\right)$ and $(\mathrm{OR}=$ $\left.11.95,95 \% \mathrm{CI}=[3.41-41.91], \chi^{2}=22.5 ; \mathrm{p}<0.05\right)$, whereas allele $\mathrm{C}-174$ was associated with a decrease in the risk of HF (OR $\left.=0.39,95 \% \mathrm{CI}=[0.26-0.58], \chi^{2}=22.75, \mathrm{p}<0.05\right)$ (Table II).

The present study showed the association between polymorphism of the IL-6 gene (-174G $>$ C) and HF in patients with CAD and obesity.

Several studies have reported an association between the IL-6 gene $(-174 \mathrm{G}>\mathrm{C})$ polymorphism and CAD, HF $[13,14]$. However, other studies have reported no such relation [15-18].

Our study had some limitations. First, our study has a relatively small sample size of selected patients. Secondly, it is a cross-sectional study. Further large, multicenter follow up studies are needed to confirm this relation.

\section{CONCLUSIONS}

In conclusion, the present study provides evidence that the $-174 \mathrm{G}>\mathrm{C}$ polymorphism in the IL- 6 gene is significantly associated with increased risk of HF in patients with CAD and obesity. A significant associations were found between the $-174 \mathrm{G}>\mathrm{C}$ polymorphism in the IL- 6 gene and HF risk, especially in patients with CAD and obesity. Furthermore, well-designed large population studies are needed to investigate the relation of these polymorphisms and HF.

\section{REFERENCES}

1. Elagizi A., Kachur S., LavieC., CarboneS., Pandey A., Ortega F.B., Milani R.V.An Overview and Update on Obesity and the Obesity Paradox in Cardiovascular Diseases. Prog Cardiovasc Dis. 2018; 61(2): 142-150, doi: 10.1016/j. pcad.2018.07.003.

2. Koudstaal S., Pujades-Rodriguez M., Denaxas S., Gho J.M.I.H., Shah A.D., Yu N., Patel R.S., Gale C.P., Hoes A.W., Cleland J.G., Asselbergs F.W., Hemingway H. Prognostic burden of heart failure recorded in primary care, acute hospital admissions, or both: a population-based linked electronic health record cohort study in 2.1 million people. Eur J Heart Fail. 2017; 19(9): 1119-1127, doi: 10.1002/ejhf.709.

3. Lavie C.J., Milani RV, Ventura HO. Untangling the heavy cardiovascular burden of obesity. Nat Clin Pract Cardiovasc Med. 2008; 5: 428-429, doi: 10.1038 / ncpcardio1257.

4. Ahmad F.S., Ning H., Rich J.D., Yancy C.W., Lloyd-Jones D.M., Wilkins J.T. Hypertension, Obesity, Diabetes, and Heart Failure-Free Survival: The Cardiovascular Disease Lifetime Risk Pooling Project. JACC Heart Fail. 2016; 4(12): 911-919, doi: 10.1016/j.jchf.2016.08.001.

5. Lloyd-Jones D., Adams R., Carnethon M., De Simone G., Ferguson T.B., Flegal K., Ford E., Furie K., Go A., Greenlund K., Haase N., HailpernS., Ho M., Howard V., Kissela B., Kittner S., Lackland D., Lisabeth L., Marelli A., McDermott M., Meigs J., Mozaffarian D., Nichol G., O'Donnell C., Roger V., Rosamond W., Sacco R., Sorlie P., Stafford R., Steinberger J., Thom T., Wasserthiel-Smoller S., Wong N., Wylie-Rosett J., Hong Y. American Heart Association Statistics Committee and Stroke Statistics Subcommittee Heart disease and stroke statistics-2009 update: a report from the American Heart Association Statistics Committee and Stroke Statistics Subcommittee.Circulation. 2009; 119(3): 480-486, doi: 10.1161/CIRCULATIONAHA.108.191259.
6. Libby P., Loscalzo J., Ridker P.M., Farkouh M.E., Hsue P.Y., Fuster V., Hasan A.A., Amar S. Inflammation, Immunity, and Infection in Atherothrombosis: JACC Review Topic of the Week. J Am Coll Cardiol. 2018; 72(17): 2071-2081, doi: 10.1016/j.jacc.2018.08.1043.

7. Shanker J., Kakkar V.V. Implications of genetic polymorphisms in inflammation induced atherosclerosis. Open Cardiovasc Med J. 2010; 4: 30-37, doi: 10.2174 / 1874192401004020030.

8. Packard R.R., Libby P. Inflammation in atherosclerosis: form vascular biology to biomarker discovery and risk prediction. Clin Chem. 2008; 54: 24-38, doi: 10,1373 / clinchem.2007.097360.

9. Seruga B., Zhang H., Bernstein L.J., Tannock I.F. Cytokines and their relationship to the symptoms and outcome of cancer. Nat Rev Cancer. 2008; 8: 887-899, doi: 10.1038 / nrc2507.

10. Held C., White H.D., Stewart R.A.H., Budaj A., Cannon C.P., Hochman J.S., Koenig W., Siegbahn A., Steg P.G., Soffer J., Weaver W.D., Östlund 0., Wallentin L. Inflammatory Biomarkers Interleukin-6 and C-Reactive Protein and Outcomes in Stable Coronary Heart Disease: Experiences From the STABILITY (Stabilization of Atherosclerotic Plaque by Initiation of Darapladib Therapy) Trial. STABILITY Investigators.J Am Heart Assoc. 2017; 6(10): e005077, doi: 10.1161/ JAHA.116.005077.

11. Ziegler L., Gajulapuri A., Frumento P., Bonomi A., Wallén H., de Faire U., Rose-John S., Gigante B. Interleukin 6 Trans-Signalling and Risk of Future Cardiovascular Events. Cardiovasc Res. 2018 Jul 23, doi: 10.1093/cvr/cvy191.

12. Zhang H., Liu C., Zhao B., Zhou X. An Evidence-Based Meta-Analysis on the Roles of Functional Interleukin-6 Polymorphisms in Coronary Artery Disease. J Interferon Cytokine Res. 2018; 38(9):370-377, doi: 10.1089/ jir.2018.0075.

13. Çelik A., Özçetin M., Ateş Ö., Altunkaş F., Karaman K., Akar I., İnce I.., Yalçın M., Karayakalı M., Ceyhan K., Koç F.. Analyses of C-Reactive Protein, Endothelial Nitric 0xide Synthase and Interleukin-6 Gene Polymorphisms in Adolescents with a Family History of Premature Coronary Artery Disease: A Pilot Study. Balkan Med J. 2015; 32(4): 397-402, doi: 10.5152/balkanmedj.

14. Aker S., Bantis C., Reis P., Kuhr N., Schwandt C., Grabensee B., Heering P., Ivens K. Influence of interleukin-6 G-174C gene polymorphism on coronary artery disease, cardiovascular complications and mortality in dialysis patients. Nephrol Dial Transplant. 2009; 24(9): 2847-2851, doi: 10.1093 / ndt / gfp141.

15. Hou H., Wang C., Sun F., Zhao L., Dun A., Sun Z. Association of interleukin-6 gene polymorphism with coronary artery disease: an updated systematic review and cumulative meta-analysis. Inflamm Res. 2015; 64(9): 707-720, doi: 10.1007/s00011-015-0850-9.

16. Szpakowicz A., Pepinski W., Waszkiewicz E., Skawronska M., Niemcunowicz-Janica A., Musial W.J., Kaminski K.A. The rs2228145 polymorphism in the interleukin-6 receptor and its association with long-term prognosis after myocardial infarction in a pilot study. Arch Med Sci. 2017; 13(1): 93-99, doi: 10.5114/ aoms.2016.58636.

17. Nauck M., Winkelmann B.R., Hoffmann M.M., Böhm B.O., Wieland H., März W. The interleukin- $6 \mathrm{G}(-174)$ C promoter polymorphism in the LURIC cohort: no association with plasma interleukin-6, coronary artery disease, and myocardial infarction. J Mol Med. 2002; 80:507-513, doi: 10,1007 / s00109-002-0354-2.

18. Zhou J., Feng J., LiX. Association between the $-174 \mathrm{G} / \mathrm{C}$ polymorphism of the interleukin- 6 gene and myocardial infarction risk: a meta-analysis. Genet Mol Res. 2016; 15(3), doi: 10.4238/gmr.15038358. 
The work is performed within research of Department of Internal Medicine №2, Clinical Immunology and Allergology named after L.T. Malaya of the Kharkiv National Medical University "Coronary artery disease in the conditions of a polymorbydity: pathogenetic aspects of development, current, diagnostics and improvement of the treatment" (№0118U000929), the term of performance is 2017-2019.

\section{ORCID and contributionship:}

Pavlo G. Kravchun: 0000-0002-8285-6763 ${ }^{F}$

Olga I. Kadykova: 0000-0002-0108-0597 ${ }^{D}$

Natalia G. Ryndina: 0000-0002-1815-1965 ${ }^{\mathrm{E}}$

Svitlana O. Krapivko: 0000-0002-1442-933X ${ }^{B}$

Mykhailo I. Kozhyn: 0000-0002-8359-8890 A

Victoriia I. Zolotaikina: 0000-0002-5265-4861 ${ }^{\mathrm{C}}$

\section{Conflict of interest:}

The Authors declare no conflict of interest.

\section{CORRESPONDING AUTHOR}

\section{Olga I. Kadykova}

Kharkiv National Medical University

4 Nauky st., 61022 Kharkiv, Ukraine

tel: +380508115557

e-mail: kadykova.olga1985@gmail.com

Received: 15.10 .2019

Accepted: 02.06 .2020

A - Work concept and design, B - Data collection and analysis, C - Responsibility for statistical analysis,

D-Writing the article, $\mathbf{E}$-Critical review, $\mathbf{F}$ - Final approval of the article 